\title{
KAJIAN URAIAN PEKERJAAN DAN PEMETAAN KOMPETENSI : STUDI KASUS PADA PERUSAHAAN PENGEMBANG PROPERTI DI SURABAYA
}

\section{REVIEW OF JOB DESCRIPTION AND COMPETENCY MAPPING : CASE STUDY AT THE PROPERTY DEVELOPER COMPANY IN SURABAYA}

\author{
Bernadetta Filinia \\ Universitas Surabaya \\ Email: bernadettafilinia@gmail.com
}

\begin{abstract}
ABSTRAK
Analisa jabatan merupakan salah satu teknik yang penting dalam Manajemen Sumber daya Manusia untuk menyediakan informasi mengenai tanggung jawab suatu jabatan dan karakteristik individu yang diperlukan untuk menjalankan tanggung jawab tersebut. Tujuan penelitian ini adalah melaksanakan analisa jabatan pada salah satu perusahaan pengembang properti di Surabaya untuk menunjang pembaharuan uraian pekerjaan perusahaan. Penelitian ini menggunakan metode kualitatif dengan proses pengumpulan data menggunakan wawancara dan studi literatur. Penelitian ini menghasilkan uraian pekerjaan yang relevan dengan tanggung jawab rutin pemegang jabatan, kompetensi yang diperlukan pemegang jabatan untuk melaksanakan tanggung jawab tersebut serta kesenjangan kompetensi dan area pengembangan pemegang jabatan yang diperoleh melalui proses wawancara berbasis perilaku.
\end{abstract}

Kata Kunci: jabatan, pemetaan, kompetensi, pemegang tanggung jawab, sumber daya manusia

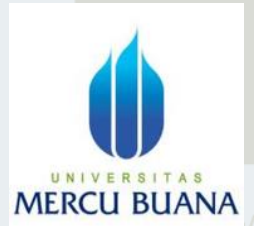

Jurnal Perilaku Dan Strategi Bisnis

Vol.8 No.2, 2020

Hal. $108-118$

Job analysis is one of the important techniques in Human Resources Management to provide the information about job responsibilities and individual characteristics that required to accomplish the job. The purposed of this research is to conduct the job analysis at one of the property developer company in Surabaya for updating the company's job descriptions. This research used a qualitative method with interview and literature study for collecting information. The results of this research were job descriptions that relevant with the latest responsibilities of job holder, the required competencies of job holder for accomplish the job, the competencies gap and job holder's development area that obtained from behavioral based interview.

Keywords: job, description, competency, job holder, human resource 


\section{PENDAHULUAN}

Manajemen sumber daya manusia (Human Resource Management) merupakan suatu pendekatan strategis dan terintegrasi untuk penempatan, pengembangan dan kesejahteraan sumber daya manusia yang tergabung dalam organisasi. Pendekatan manajemen sumber daya manusia berfokus pada cara organisasi dalam menempatkan dan mengelola sumber daya manusia yang dimiliki (Armstrong, 2009). Manajemen sumber daya manusia menjadi penting karena dapat memastikan organisasi mencapai tujuan melalui sumber daya manusia dengan cara mencegah organisasi memperkerjakan individu yang tidak sesuai kualifikasi ataupun sumber daya manusia yang tidak bekerja secara maksimal. Organisasi yang sukses adalah organisasi yang mengetahui cara menemukan sumber daya manusia yang tepat untuk jabatan yang dibutuhkan serta cara mengembangkan sumber daya manusia tersebut (Dessler, 2013). Selain itu, tantangan yang dihadapi organisasi saat ini sudah berbeda dengan masa lalu sehingga jajaran manajemen perlu menempatkan organisasi agar dapat beradaptasi dengan kebutuhan yang baru (Daft, 2010). Salah satu tantangannya seperti perkembangan industri, globalisasi dan teknologi saat ini membuat organisasi perlu memikirkan strategi-strategi dalam mengelola sumber daya manusia. Hal kritis yang dihadapi organisasi adalah mengetahui kompetensi sumber daya manusia yang ada dan mengembangkannya untuk menghadapi industri yang kompetitif saat ini. Hal tersebut menjadi penting karena salah satu aset utama organisasi dalam mencapai kesuksesan adalah sumber daya manusia yang kompeten (Worlikar \& Aggrawal, 2017).

Manajemen sumber daya manusia dimulai dengan memahami terlebih dahulu jabatan yang dibutuhkan organisasi serta karakteristik dan kompetensi sumber daya manusia yang diperlukan untuk melaksanakan tanggung jawab jabatan tersebut secara efektif (Dessler, 2013). Oleh karena itu, analisa jabatan (job analysis) menjadi sebuah metode yang penting dalam manajemen sumber daya manusia (Armstrong, 2009). Analisa jabatan merupakan sebuah proses untuk menentukan tanggung jawab suatu jabatan dan karakteristik yang diperlukan untuk menjalankan tanggung jawab tersebut. Analisa jabatan akan menghasilkan uraian pekerjaan (job descriptions) serta karakteristik sumber daya manusia yang diperlukan (job specifications). Pada dasarnya, setiap proses dasar manajemen sumber daya manusia seperti wawancara calon karyawan, pelatihan maupun penilaian karyawan bergantung kepada informasi yang tercantum dalam uraian pekerjaan terkait tanggung jawab jabatan dan karakteristik individu yang dibutuhkan untuk melaksanakan tanggung jawab tersebut (Dessler, 2013).

Uraian pekerjaan yang menjadi dasar dari berbagai fungsi manajemen sumber daya manusia menjadi alasan pentingnya uraian pekerjaan yang tersusun secara tepat dan akurat. Uraian pekerjaan digunakan mulai dari panduan untuk karyawan baru mengenai tanggung jawab yang harus diselesaikan sampai dengan evaluasi kinerja karyawan untuk menentukan struktur kompensasi yang tepat (Raju \& Banerjee, 2017). Oleh karena itu, organisasi perlu memastikan bahwa uraian pekerjaan yang tertulis tetap relevan dengan tanggung jawab yang dilaksanakan pemegang jabatan sehari-hari. Uraian pekerjaan yang tepat dan relevan akan membantu organisasi dalam membuat perencanaan tenaga kerja dan menjaga bisnis organisasi tetap efektif (Tyler, 2013). Hal tersebut didukung oleh penelitian Raju \& Banerjee (2017) yang menemukan bahwa uraian pekerjaan yang jelas dan diperbaharui sesuai kondisi karyawan menunjang pencapaian kinerja karyawan maupun organisasi.

Penelitian ini dilaksanakan di sebuah perusahaan pengembang properti di Surabaya yang telah berdiri selama 40 tahun. Perusahaan tersebut melayani kebutuhan hidup masyarakat dengan menyediakan tempat tinggal, gedung perkantoran, ritel, kawasan industri dan lain-lain. Perusahaan yang sudah cukup lama berdiri di kota Surabaya ini juga menghadapi tantangan perubahan industri saat ini. 
Berdasarkan hasil wawancara peneliti bersama tim sumber daya manusia perusahaan, saat ini perusahaan sedang memulai untuk menerapkan sistem manajemen talenta berbasis kompetensi demi pengembangan sumber daya manusia dalam mendukung kesuksesan perusahaan. Hal tersebut menyebabkan perusahaan membutuhkan uraian pekerjaan untuk dijadikan dasar pemetaan kompetensi dan juga penyusunan metode asesmen. Namun, hal yang terjadi di perusahaan adalah dokumen deskripsi pekerjaan yang dimiliki sudah tidak sesuai dengan pekerjaan yang dilakukan sehari-hari oleh pemegang jabatan. Hal tersebut dikonfirmasi oleh peneliti dengan melakukan wawancara kepada pemegang jabatan dan membandingkan hasilnya dengan dokumen uraian pekerjaan yang dimiliki perusahaan. Hasil yang ditemukan adalah terdapat pekerjaan yang dilakukan oleh pemegang jabatan namun tidak tertulis di dalam dokumen uraian pekerjaan atau sebaliknya. Hal tersebut berarti terdapat gap antara pekerjaan pemegang jabatan dengan dokumen uraian pekerjaan perusahaan sehingga dokumen tersebut menjadi tidak relevan. Sementara, perusahaan memiliki tujuan untuk dapat menerapkan sistem manajemen talenta berbasis kompetensi. Oleh karena itu, pembaharuan uraian pekerjaan dirasa perlu dilakukan untuk dapat memenuhi harapan dan tujuan perusahaan.

Tujuan dari penelitian ini adalah melakukan analisa jabatan untuk mendapatkan uraian pekerjaan yang relevan dengan tanggung jawab rutin pemegang jabatan. Hasil kajian uraian pekerjaan tersebut kemudian akan digunakan sebagai dasar penentuan dan pengukuran kompetensi pemegang jabatan dalam penerapan sistem manajemen talenta. Pengukuran kompetensi dilakukan untuk membantu pemegang jabatan menentukan area pengembangan sehingga individu tersebut dapat merencanakan program pengembangan secara mandiri (Tamilarasi, 2015). Selain itu, kesenjangan kompetensi yang ditemukan melalui pengukuran kompetensi dapat digunakan untuk menentukan pelatihan yang tepat agar pemegang jabatan dapat bekerja secara lebih efektif (Tamilarasi, 2015). Pada penelitian ini, penentuan dan pengukuran kompetensi pemegang jabatan juga akan digunakan sebagai bahan pertimbangan perusahaan untuk memetakan talenta di masa depan.

Salah satu cara yang dapat digunakan untuk pengukuran kompetensi adalah wawancara berbasis perilaku (Behavioral Based Interview). Teknik wawancara tersebut merupakan jenis wawancara terstruktur yang digunakan untuk mengumpulkan informasi mengenai perilaku di masa lalu (Tamilarasi, 2015). Pengalaman di masa lalu dipercaya dapat memprediksi perilaku di masa depan sehingga setiap panduan wawancara berbasis perilaku dirancang untuk mengungkap kinerja di masa lalu terkait keterampilan kritis yang diperlukan untuk memenuhi kompetensi tertentu (Tamilarasi, 2015). Hasil dari proses wawancara berbasis perilaku yang diharapkan adalah informasi mengenai kesenjangan kompetensi pemegang jabatan untuk menjadi dasar pengambilan keputusan terkait tindak lanjut area pengembangan sumber daya manusia yang dimiliki perusahaan.

\section{METODE PENELITIAN Jenis Penelitian}

Desain penelitian yang digunakan dalam penelitian ini adalah desain penelitian kualitatif dengan menggunakan paradigma pragmatis dalam memahami dan menyelesaikan permasalahan penelitian. Peneliti menggunakan paradigma pragmatis karena penelitian ini akan berfokus pada solusi atau tindakan yang dapat diterapkan untuk menyelesaikan permasalahan yang terjadi pada perusahaan. Paradigma tersebut juga dirasa sesuai karena peneliti bebas menentukan metode, teknik dan prosedur penelitian yang paling sesuai dengan kebutuhan serta tujuan penelitian. Paradigma pragmatis juga akan menggunakan beberapa metode pengambilan data (kualitatif dan kuantitatif) yang terbaik demi menjawab pertanyaan penelitian dan akan berfokus pada implikasi praktis dari hasil penelitian 
(Creswell, 2007). Penelitian ini juga berfokus pada implikasi praktis yang dapat diterapkan dalam perusahaan untuk menyelesaikan permasalahan.

Berdasarkan paradigma pragmatism yang telah dijelaskan di atas maka peneliti akan menggunakan pendekatan studi kasus sebagai metode pengambilan data. Peneliti menggunakan pendekatan studi kasus sebagai metode pengambilan data karena peneliti membutuhkan data terperinci dan mendalam mengenai uraian pekerjaan pemegang jabatan untuk dapat melakukan pengukuran kompetensi. Pengambilan data tersebut juga akan dilakukan dengan berbagai metode seperti wawancara dan studi dokumen untuk mendapatkan kondisi yang dihadapi oleh pemegang jabatan tersebut. Pengambilan data yang intensif pada pemegang jabatan yang menjadi sampel penelitian perlu dilakukan untuk memahami lebih lanjut mengenai uraian pekerjaan tersebut sehingga peneliti dapat menentukan kompetensi yang tepat pada pemegang jabatan. Studi kasus merupakan pendekatan yang paling memungkinkan untuk mendapatkan data yang diperlukan oleh peneliti dalam menjawab permasalahan penelitian.

\section{Subjek Penelitian}

Pengumpulan data dilakukan dengan metode wawancara kepada pemegang jabatan maupun tim sumber daya manusia perusahaan. Metode wawancara dilaksanakan dengan teknik wawancara terstruktur serta dilengkapi dengan data studi literatur dan dokumen perusahaan. Populasi pada peneltian ini adalah semua jabatan yang terdapat dalam divisi Property Management Gedung X yang merupakan salah satu unit bisnis perusahaan yang berjumlah 6 jabatan dengan rincian sebagai berikut :

1. 6 jabatan setingkat Staf

2. 8 jabatan setingkat Supervisor

3. 4 jabatan setingkat Chief

4. 1 jabatan setingkat Deputy of General Manager

5. 1 jabatan setingkat General Manager.

Penelitian ini dibatasi pada 2 jabatan berdasarkan tingkat urgensi perusahaan yaitu 1 jabatan setingkat Chief dan 1 jabatan setingkat Deputy of General Manager di divisi Property Management.

\section{Data}

Sumber data yang digunakan dalam penelitian ini adalah sebagai berikut :

1. Individu yang menjadi pemegang jabatan

2. Tim sumber daya manusia perusahaan

3. Uraian pekerjaan dari perusahaan lain dengan posisi yang mirip atau sama dengan pemegang jabatan

4. Dokumen uraian pekerjaan sebelumnya

5. Struktur organisasi

6. Kamus kompetensi perusahaan dan ilmiah

(Kamus Spencer \& Spencer, 1993 \& Kamus Loma, 1998)

\section{HASIL DAN PEMBAHASAN}

Berdasarkan hasil analisa jabatan yang dilakukan dengan wawancara bersama pemegang jabatan, peneliti menemukan kesenjangan/ketidaksesuaian dokumen uraian pekerjaan yang dimiliki perusahaan dengan tanggung jawab rutin pemegang jabatan. Ketidaksesuaian yang ditemukan adalah beberapa tanggung jawab yang merupakan serangkaian proses kerja sehingga dapat digabungkan menjadi 1 tanggung jawab pekerjaan. Selain itu, ketidaksesuaian yang lain adalah tanggung jawab pekerjaan yang sudah tidak sesuai dengan aktivitas kerja rutin pemangku jabatan sehingga dapat 
dihapuskan serta tanggung jawab pekerjaan yang ditambahkan karena belum dicantumkan dalam dokumen perusahaan namun dilaksanakan oleh pemegang jabatan.

Hal lain yang ditemukan peneliti adalah bahasa yang digunakan dalam penjabaran uraian pekerjaan masih ambigu sehingga bahasa penulisan disesuaikan menggunakan kata kerja yang mampu menjabarkan tanggung jawab pekerjaan secara jelas. Upaya perbaikan uraian pekerjaan yang dilakukan peneliti adalah sebagai berikut :

1. Beberapa tanggung jawab merupakan serangkaian proses kerja sehingga digabungkan menjadi 1 tanggungjawab utama

2. Bahasa dalam uraian pekerjaan disesuaikan menggunakan kata kerja yang dapat dipahami secara lebih jelas

3. Tanggung jawab sudah tidak sesuai dengan aktivitas kerja rutin pemegang jabatan sehingga dapat dihapuskan

4. Tanggung jawab rutin yang dilaksanakan oleh pemegang jabatan dan signifikan terhadap penilaian kinerja namun belum tercantum dalam dokumen uraian pekerjaan sehingga dapat ditambahkan

Selain itu, uraian pekerjaan kemudian dikelompokkan menjadi dua yaitu tanggung jawab utama dan penunjang. Tanggung jawab utama merupakan tanggung jawab yang rutin dilaksanakan dalam operasional pekerjaan pemegang jabatan dan mempengaruhi penilaian kinerja sedangkan tanggung jawab penunjang merupakan tanggung jawab yang dilaksanakan secara situasional dan bersifat menunjang tanggung jawab utama serta tidak signifikan dalam penilaian kinerja.

Contoh upaya perbaikan uraian pekerjaan yang dilakukan oleh peneliti dijabarkan dalam tabel berikut:

Tabel 1. Contoh Upaya Perbaikan Uraian Pekerjaan

\begin{tabular}{|c|c|c|c|}
\hline No & $\begin{array}{c}\text { Uraian Pekerjaan } \\
\text { Lama }\end{array}$ & Hasil Kajian & Uraian Pekerjaan Baru \\
\hline 1 & $\begin{array}{lr}\text { Menjalankan } & \text { fungsi } \\
\text { monitoring } & \text { terhadap } \\
\text { konsultan } \quad \text { properti } \\
\text { dalam melaksanakan } \\
\text { persiapan r projek } \\
\text { pembangunan properti }\end{array}$ & Tanggung jawab & \begin{tabular}{lrr} 
Mengawasi & \multicolumn{2}{c}{ konsultan } \\
properti mulai dari
\end{tabular} \\
\hline 2 & $\begin{array}{lr}\text { Menjalankan } & \text { fungsi } \\
\text { monitoring } & \text { terhadap } \\
\text { konsultan r properti } & \text { menjalankan } \\
\text { dalam } r \text { mrojek } & \text { operasional r properti }\end{array}$ & \begin{tabular}{lr}
\multicolumn{2}{l}{ digabungkan karena ketiga } \\
tanggung jawab & tersebut \\
merupakan & rangkaian \\
proses dalam & fungsi \\
monitoring & terhadap \\
konsultan properti &
\end{tabular} & 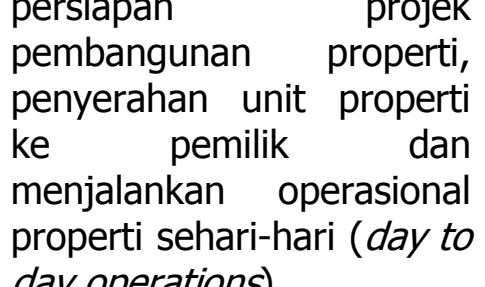 \\
\hline 3 & $\begin{array}{l}\text { Memastikan proses } \\
\text { serah terima unit } \\
\text { properti kepada pemilik } \\
\text { berjalan sesuai jadwal }\end{array}$ & & \\
\hline 4 & $\begin{array}{l}\text { Melaksanakan tanggung } \\
\text { jawab untuk } \\
\text { pencapaian target kerja }\end{array}$ & $\begin{array}{lr}\text { Tanggung } & \text { jawab } \\
\text { dihapuskan karena tidak } \\
\text { termasuk dalam bagian } \\
\text { aktivitas kerja rutin }\end{array}$ & - \\
\hline 5 & - & $\begin{array}{lr}\text { Tanggung } & \text { jawab } \\
\text { ditambahkan karena rutin } \\
\text { dilaksanakan } & \text { pemegang } \\
\text { jabatan dalam operasional }\end{array}$ & $\begin{array}{l}\text { Membuat } \\
\text { anggaran } \\
\text { selama } 1 \\
\text { mengontrol }\end{array}$ \\
\hline
\end{tabular}




\begin{tabular}{|c|c|c|c|}
\hline No & $\begin{array}{c}\text { Uraian Pekerjaan } \\
\text { Lama }\end{array}$ & Hasil Kajian & Uraian Pekerjaan Baru \\
\hline 6 & $\begin{array}{l}\text { Mengembangkan } \\
\text { kompetensi Sumber } \\
\text { Daya Manusia secara }\end{array}$ & $\begin{array}{l}\text { pekerjaan } \\
\text { Penggunaan kata kerja } \\
\text { disesuaikan } \\
\text { penjabaran tanqqung jawab }\end{array}$ & $\begin{array}{l}\text { penggunaannya } \\
\text { Membimbing anggota tim } \\
\text { (Sumber Daya Manusia) } \\
\text { dalam mengembangkan }\end{array}$ \\
\hline & maksimal & lebih dapat dipahami & $\begin{array}{l}\text { kompetensinya secara } \\
\text { maksimal. }\end{array}$ \\
\hline
\end{tabular}

Berdasarkan proses analisa jabatan yang telah diuraikan sebelumnya maka peneliti mengajukan perubahan uraian pekerjaan untuk jabatan Deputy of General Manager yaitu 6 tanggung jawab yang baru dari total 8 tanggung jawab sebelumnya. Perubahan tanggung jawab tersebut dikarenakan terdapat beberapa tanggung jawab yang merupakan satu kesatuan proses sehingga digabungkan menjadi 1 tanggung jawab utama. Sedangkan, perubahan untuk jabatan Chief Engineer yaitu 6 tanggung jawab yang baru dari 4 tanggung jawab sebelumnya. 6 tanggung jawab terdiri dari 5 tanggung jawab utama dan 1 tanggung jawab penunjang. Perubahan tanggung jawab dilakukan karena terdapat tanggung jawab yang rutin dilaksanakan namun belum termasuk dalam uraian pekerjaan sebelumnya sehingga dirasa perlu untuk ditambahkan menjadi tanggung jawab utama dalam uraian pekerjaan yang baru.

Berdasarkan uraian pekerjaan yang telah ditentukan maka tahap selanjutnya adalah menentukan kompetensi kritis dan standar level kompetensi yang akan menjadi acuan dalam proses wawancara berbasis perilaku (Behavioral Based Interview). Penentuan kompetensi kritis mengacu kepada kamus kompetensi yang telah dimiliki oleh perusahaan. Kamus kompetensi perusahaan disusun berdasarkan kamus kompetensi Spencer \& Spencer (1993) serta LOMA (1998). Terdapat 3 jenis kompetensi yang dimiliki oleh perusahaan yaitu sebagai berikut :

1. Kompetensi inti (core competencies) yaitu kompetensi yang harus dimiliki oleh seluruh karyawan

2. Kompetensi role (role competencies) yaitu kompetensi yang harus dimiliki oleh karyawan yang berada di jenjang manajerial

3. Kompetensi spesifik (specific competencies) yaitu kompetensi yang harus dimiliki berdasarkan jabatan masing-masing.

Jenis kompetensi yang digunakan dalam pengukuran kompetensi pemegang jabatan adalah kompetensi role (role competencies). Pemilihan kompetensi tersebut ditentukan karena kebutuhan perusahaan untuk mengetahui kesesuaian kompetensi pemegang jabatan dengan standar kompetensi untuk perannya di jenjang manajerial. Kompetensi role yang digunakan dijabarkan melalui tabel berikut: 
Tabel 2. Kompetensi Role (Role Competencies)

\begin{tabular}{|c|c|c|}
\hline No & Kompetensi & Definisi \\
\hline 1 & Developing Others & $\begin{array}{l}\text { Adanya kemauan untuk mendorong perkembangan orang } \\
\text { lain dengan menyediakan lingkungan yang mendukung } \\
\text { untuk meningkatkan pertumbuhan prestasi dan } \\
\text { profesional. }\end{array}$ \\
\hline 2 & Chance Leadership & Memimpin dan mengelola perubahan \\
\hline 3 & Business Acumen & $\begin{array}{l}\text { Memahami prinsip-prinsip bisnis pada umumnya, } \\
\text { dinamika industri, dan sistem operasional perusahaan } \\
\text { untuk mendukung kelancaran pekerjaan dan } \\
\text { pengembangan usaha perusahaan. }\end{array}$ \\
\hline 4 & Strategic Thinking & $\begin{array}{l}\text { Memahami dan mengembangkan visi dan strategi yang } \\
\text { berorientasi pada masa depan dengan menggunakan } \\
\text { pengetahuan dan perhitungan analisa yang memadai } \\
\text { tentang faktor-faktor internal dan eksternal. }\end{array}$ \\
\hline
\end{tabular}

Penyusunan jenjang (level) kompetensi dirancang berdasarkan Taksonomi Bloom yang dijelaskan melalui tabel beriku:

Tabel 3. Jenjang (Level) Kompetensi

\begin{tabular}{|c|c|c|}
\hline & Level & Keterangan \\
\hline 5 & Expert & $\begin{array}{l}\text { Penguasaan pada level perilaku ini berarti dapat mengembangkan } \\
\text { atau menciptakan suatu sistem atau suasana kerja dalam lingkup } \\
\text { divisi yang dapat meningkatkan kinerja dan produktivitas karyawan } \\
\text { sehingga menjadi lebih baik, efektif, dan efisien dibandingkan sistem } \\
\text { terdahulu. Level penguasaan perilaku ini dituntutkan pada jabatan } \\
\text { pegawai setingkat dengan pejabat puncak setingkat Kepala Divisi } \\
\text { atau General Manager. }\end{array}$ \\
\hline 4 & Mastery & $\begin{array}{l}\text { Level penguasaan perilaku ini dituntutkan pada jabatan pegawai } \\
\text { setingkat dengan Kepala Urusan atau Manager. }\end{array}$ \\
\hline 3 & $\begin{array}{l}\text { Skillful } \\
\text { Application }\end{array}$ & $\begin{array}{l}\text { Penguasaan pada level perilaku ini berarti dapat melaksanakan } \\
\text { aktivitas kerja secara proaktif (tanpa perlu menunggu perintah) dan } \\
\text { mampu melakukan analisa terhadap kondisi pekerjaan yang } \\
\text { dihadapi, guna mencapai hasil kerja yang melebihi target yang } \\
\text { ditetapkan. Level penguasaan perilaku ini dituntutkan pada jabatan } \\
\text { pegawai setingkat dengan Staf atau Kepala Seksi }\end{array}$ \\
\hline 2 & $\begin{array}{l}\text { Basic } \\
\text { Application }\end{array}$ & $\begin{array}{l}\text { Penguasaan pada level perilaku ini berarti dapat melaksanakan } \\
\text { aktivitas kerja sehari-hari sesuai dengan aturan, cara, dan prosedur } \\
\text { yang berlaku dalam perusahaan secara pasif atau responsif (ketika } \\
\text { diminta). Level penguasaan perilaku ini dituntutkan pada jabatan } \\
\text { pegawai setingkat dengan Pengawas atau Asisten Staf. }\end{array}$ \\
\hline 1 & Awareness & $\begin{array}{l}\text { Penguasaan pada level perilaku ini berarti sebatas memiliki } \\
\text { pengetahuan dan pemahaman mengenai nilai, norma, aturan, serta } \\
\text { prosedur kerja dalam perusahaan. Level penguasaan perilaku ini } \\
\text { dituntutkan pada jabatan pegawai setingkat dengan level Operator } \\
\text { atau Admin. }\end{array}$ \\
\hline
\end{tabular}

Penataan standar kompetensi pemegang jabatan dilakukan dengan membandingkan uraian pekerjaan, jenis serta jenjang kompetensi. Hasil penataan standar kompetensi untuk jabatan Deputy of General Manager adalah level 4 untuk kompetensi Developing Others dan 
Change Leadership. Hal tersebut dikarenakan uraian pekerjaan jabatan Deputy of General Manager memerlukan level kompetensi tersebut dalam tingkatan melakukan evaluasi pada bawahan maupun prosedur serta menemukan solusi yang efektif dalam pelaksanaan pekerjaan sehari-hari, kemudian level 5 untuk kompetensi Business Acumen dan Strategic Thinking dikarenakan uraian pekerjaan jabatan Deputy of General Manager memerlukan level kompetensi tersebut dalam tingkatan melakukan mengembangkan suatu sistem untuk produktifitas yang lebih baik.

Hasil penataan standar kompetensi untuk jabatan Chief Engineer adalah level 4 untuk keempat kompetensi. Hal tersebut dikarenakan uraian pekerjaan jabatan Chief Engineer memerlukan level kompetensi tersebut dalam tingkatan melakukan evaluasi pada bawahan maupun prosedur serta menemukan solusi yang efektif dalam pelaksanaan pekerjaan sehari-hari

Tahap selanjutnya adalah merumuskan panduan wawancara berbasis perilaku untuk pengukuran kesenjangan kompetensi yang dimiliki pemegang jabatan dengan standar yang telah ditetapkan. Pada penelitian ini, rancangan pertanyaan wawancara berbasis perilaku disusun untuk jabatan setingkat Chief dan wawancara dilaksanakan bersama pemegang jabatan Chief Engineer. Contoh rancangan pertanyaan wawancara berbasis perilaku yang digunakan dalam penelitian ini adalah sebagai berikut :

Tabel 4. Rancangan Panduan Wawancara Berbasis Perilaku

\section{Developing Others}

\section{Definisi :}

Menyediakan kesempatan untuk pembelajaran

\section{Indikator :}

Memastikan bahwa tersedia waktu \& sumber untuk aktifitas pengembangan.

\section{Situasi (Situation)}

Ceritakan pengalaman

Anda dalam menyediakan waktu dan sumber untuk aktivitas pengembangan tim

$$
\text { tim }
$$

Definisi :

Mengintegrasikan inisiatif perubahan dengan sasaran perusahaan.

\section{Tugas (Task)}

Seperti apa peran
Anda dalam situasi
tersebut?

\section{Aksi (Action)}

Langkah-langkah apa yang Anda lakukan?

\section{Result}

(Hasil)

Bagaimana tanggapan tim

Anda?

\begin{tabular}{|c|c|c|c|}
\hline Situasi (Situation) & Tugas (Task) & Aksi (Action) & $\begin{array}{l}\text { Result } \\
\text { (Hasil) }\end{array}$ \\
\hline $\begin{array}{lr}\text { Ceritakan pengalaman } \\
\text { Anda bersama tim Anda } \\
\text { dalam mengembangkan } \\
\text { sebuah } \\
\text { menghadapi } & \text { strategi } \\
\text { mengelola } & \text { dan } \\
\text { perubahan! } & \text { suatu } \\
& \end{array}$ & $\begin{array}{l}\text { Sejauh mana Anda } \\
\text { terlibat dalam } \\
\text { kegiatan tersebut? }\end{array}$ & $\begin{array}{l}\text { 1. Bagaimana cara } \\
\text { Anda dan tim } \\
\text { Anda } \\
\text { mengembangkan } \\
\text { sebuah strategi } \\
\text { tentang } \\
\text { perubahan itu? } \\
\text { 2. Bagaimana cara } \\
\text { Anda melakukan } \\
\text { koordinasi }\end{array}$ & $\begin{array}{l}\text { 1. Apakah } \\
\text { strategi } \\
\text { yang Anda } \\
\text { dan tim } \\
\text { berhasil } \\
\text { diterapkan? } \\
\text { 2. Bagaimana } \\
\text { hasil } \\
\text { evaluasi } \\
\text { dari strategi }\end{array}$ \\
\hline
\end{tabular}




\begin{tabular}{|c|c|}
\hline & $\begin{array}{l}\text { dengan } \\
\text { Anda? }\end{array}$ \\
\hline \multicolumn{2}{|c|}{ Business Acumen } \\
\hline $\begin{array}{l}\text { Definisi : } \\
\text { Memahami arah strategi perusahaan dan } \\
\text { implikasinya }\end{array}$ & $\begin{array}{l}\text { Indikator: } \\
\text { Memahami arah strategi per } \\
\text { dan implikasinya }\end{array}$ \\
\hline Situasi (Situation) & Aksi (Action) \\
\hline $\begin{array}{lrrl}\text { Ceritakan pengalaman } & \text { 1. } & \text { Apa peran Anda } \\
\text { Anda saat } & \text { harus } & & \text { pada waktu itu? } \\
\text { menerapkan strategi } & \text { 2. } & \text { Tanggungjawab } \\
\text { bisnis yang dimiliki } & & \text { apa y yang } \\
\text { perusahaan ke dalam } & & \text { diberikan pada } \\
\text { pekerjaan sehari-hari. } & & \text { Anda waktu itu? }\end{array}$ & $\begin{array}{ll}\text { Langkah-langkah } & \text { Bagaimana } \\
\text { apa saja yang Anda } & \text { hasilnya? } \\
\text { lakukan dalam } & \\
\text { mengatasi masalah } \\
\text { tersebut? }\end{array}$ \\
\hline \multicolumn{2}{|c|}{ Strategic Thinking } \\
\hline $\begin{array}{l}\text { Definisi : } \\
\text { Mendorong keterlibatan kelompok/tim }\end{array}$ & $\begin{array}{l}\text { Indikator: } \\
\text { Menetapkan persoalan, } \\
\text { menghasilkan pilihan dan memilih } \\
\text { solusi pemecahannya yang konsisten } \\
\text { dengan strategi dan visi perusahaan }\end{array}$ \\
\hline Situasi (Situation) & $\begin{array}{l}\text { Result } \\
\text { (Hasil) }\end{array}$ \\
\hline \begin{tabular}{lll} 
Coba ceritakan salah satu & 1. & \multicolumn{2}{l}{ Bagaimana peran } \\
pengalaman ketika Anda & & Anda di situasi \\
menganalisis suatu & \multicolumn{2}{l}{ tersebut? } \\
kendala dan mengambil & 2. Apa tanggung \\
keputusan untuk & jawab Anda \\
memecahkan masalah. & waktu itu?
\end{tabular} & $\begin{array}{ll}\text { Langkah-langkah } & \text { Bagaimana } \\
\text { apa saja yang Anda } & \text { hasilnya? } \\
\text { lakukan? } & \end{array}$ \\
\hline
\end{tabular}

Berdasarkan hasil analisa dalam penelitian ini, peneliti menemukan bahwa uraian pekerjaan perusahaan sudah tidak sesuai dengan pekerjaan rutin yang dilakukan oleh pemegang jabatan. Oleh karena itu, penelitian ini dilakukan untuk menyediakan uraian pekerjaan yang sesuai dengan kondisi pekerjaan rutin pemegang jabatan melalui metode analisa jabatan. Hal tersebut dilakukan agar uraian pekerjaan yang dimiliki perusahaan dapat digunakan untuk menentukan kompetensi dan standar kompetensi yang diperlukan untuk jabatan tersebut agar dapat bekerja sesuai harapan perusahaan.

Pada penataan dan penentuan standar kompetensi, pemegang jabatan setingkat Chief ditetapkan standar pada level 4 yaitu Mastery. Hal tersebut disebabkan oleh jabatan setingkar Chief berada di jajaran manajerial yang diharapkan dapat mengevaluasi kinerja bawahan dan juga proses kerjanya sehingga dapat merumuskan solusi maupun inovasi baru demi kinerja tim yang lebih baik untuk mencapai tujuan perusahaan. Hal tersebut juga diterapkan pada jabatan setingkat Deputy of General Manager. Namun, terdapat beberapa kompetensi yang ditetapkan pada level 5 yaitu Expert. Hal tersebut dikarenakan jabatan tersebut adalah wakil dari General Manager yang diharapkan dapat membantu General Manager untuk mengevaluasi sistem yang sedang berjalan dan merumuskan saran pengembangan untuk kemajuan perusahaan.

Selanjutnya, penataan kompetensi yang telah dilakukan dapat dilanjutkan ke tahap rancangan panduan wawancara berbasis perilaku yang digunakan untuk mengukur kesenjangan antara kompetensi pemegang jabatan dengan standar kompetensi yang telah 
ditetapkan. Rancangan panduan wawancara tersebut mengacu kepada kamus kompetensi perusahaan dan disusun berdasarkan teori STAR (Situation, Task, Action dan Result).

Keseluruhan penelitian ini menghasilkan beberapa produk yaitu hasil kajian uraian pekerjaan pemegang jabatan, penataan standar kompetensi yang dibutuhkan untuk menjalankan jabatan tersebut serta panduan pertanyaan wawancara berbasis perilaku yang dapat digunakan untuk mengukur kesenjangan kompetensi pemegang jabatan. Pengujian validitas penelitian dilakukan dengan cara Triangulasi. Triangulasi merupakan pemeriksaan validitas data penelitian dengan menggunakan berbagai cara dan sumber (Sugiyono, 2015). Pada saat proses wawancara, peneliti juga melakukan dokumentasi dengan perekaman sehingga data yang diolah dapat dipastikan sesuai dengan data yang disampaikan oleh pemegang jabatan. Selain itu, hasil penelitian kemudian diperiksa dan dikonfirmasi oleh beberapa sumber yaitu dosen senior Fakultas Psikologi di instansi peneliti serta tim sumber daya manusia perusahaan. Seluruh hasil penelitian dapat diterima dan menjadi dasar pertimbangan perusahaan dalam menerapkan sistem manajemen talenta di masa depan.

\section{KESIMPULAN}

Berdasarkan hasil penelitian studi kasus yang dilaksanakan di sebuah perusahaan pengembang properti di Surabaya yang telah berdiri selama 40 tahun, maka dapat disimpulkan beberapa hal yaitu hasil analisa jabatan menunjukkan bahwa terdapat kesenjangan antara dokumen uraian pekerjaan perusahaan dengan tanggung jawab rutin pemegang jawaban dalam pekerjaan sehari-hari. Hal tersebut berarti kajian rutin terhadap uraian pekerjaan yang dimiliki perusahaan perlu dilaksanakan demi menjamin keefektifan perusahaan. Selain itu, hasil kajian uraian pekerjaan kemudian dapat digunakan sebagai dasar penentuan dan pengukuran kompetensi pemegang jabatan. Pengukuran kompetensi pemegang jabatan penting dilakukan agar pengembangan sumber daya manusia dilaksanakan tepat sesuai kebutuhan oleh perusahaan. Kesimpulan selanjutnya adalah hasil penelitian studi kasus ini menghasilkan uraian pekerjaan yang relevan dengan tanggung jawab rutin pemegang jabatan, pemetaan kompetensi pemegang jabatan serta panduan wawancara berbasis perilaku yang dapat digunakan perusahaan untuk kebutuhan sejenis di masa yang akan datang. Kemudian hasil penelitian studi kasus ini juga memberikan informasi terkait area pengembangan pemegang jabatan untuk ditindaklanjuti oleh perusahaan dan menjadi dasar pertimbangan dalam menerapkan sistem manajemen talenta di masa depan.

Berdasarkan hasil penelitian studi kasus di atas, peneliti menyarankan agar uraian pekerjaan perlu disosialisasikan kepada seluruh karyawan perusahaan sehingga setiap pemegang jabatan mengetahui tanggung jawab dan pencapaian kinerja yang diharapkan oleh perusahaan. Selain itu, pemegang jabatan yang sadar akan tanggung jawabnya juga akan menyadari jika terdapat perubahan yang harus dikaji dalam dokumen uraian pekerjaan sehingga uraian pekerjaan yang dimiliki perusahaan tetap relevan. Selain itu, peneliti selanjutnya yang tertarik untuk meneliti topik sejenis dapat mempertimbangkan untuk melakukan kajian terhadap kamus kompetensi yang dimiliki perusahaan. Hal tersebut untuk memastikan kamus kompetensi tetap relevan sesuai kamus ilmiah dan juga visi, misi dan nilai perusahaan. Kajian kamus kompetensi juga dapat menunjang kemungkinan kebutuhan akan keterampilan baru sumber daya manusia seiring dengan perkembangan industri saat ini.

\section{DAFTAR PUSTAKA}

Armstrong, M., (2009), Armstrong's Handbook of Human Resource Management Practice 11th Edition, London, UK: Kogan Page. 
Creswell, J. W., (2007), Qualitative Inquiry and Research Design : Choosing among Five Approaches 2nd Edition, London, UK : Sage Publications, Inc.

Daft, R. L., (2010), Organization Theory and Design 10th Edition, Ohio, USA : SouthWestern Cengage Learning.

Dessler, G., (2013), Human Resources Management 13th Edition, New Jersey, USA : Pearson Education, Inc.

Goodwin, C. J., (2010), Research in Psychology Methods and Design 6th Edition, New Jersey, USA : John Wiley \& Sons, Inc.

Heale, R., and Twycross, A., (2018). "What is A Case Study?", Evidence Based Nursing, Vol. 21(1), pp. 7-8.

Raju, K. K., and Banerjee, S., (2017), "A Study on Job Description and its Effect on Employee Performance : Case of Some Selected Manufacturing Organizations in the City of Pune, India", International Journal of Latest Technology in Engineering, Management \& Applied Science (IJLTEMAS), Vol. 6(2), pp. 1-10.

Spencer, L. M., and Spencer, S. M., (1993). Competence at Work : Models for Superior Performance, New Jersey, USA : John Wiley \& Sons, Inc.

Sugiyono. (2015). Metode Penelitian Pendidikan Pendekatan Kuantitatif, Kualitatif dan R\&D, Bandung, Indonesia : Penerbit Alfabeta.

Tamilarasi, S., (2015), "Managing Human Resource Through Competency Mapping", PARIPEX-Indian Journal of Research, Vol. 4(11), pp. 65-68.

Tyler, K., Job Worth Doing : Update Descriptions, https://www.shrm.org/hr-today/news/hrmagazine/pages/0113-job-descriptions.aspx, diakses 29 April 2020

Worlikar, M., and Aggrawal, A., (2017), "Review Study of Competency Mapping in the Organization", IOSR Journal of Business and Management (ISOR-JMB), e-ISSN : 2278-487X, p-ISSN : 2319-7668, pp. 72-76. 